\title{
Characterisation of multi-metal resistant Serratia sp. GP01 for treatment of effluent from fertilizer industries
}

Hrudananda Sahoo

Ravenshaw University

Sushama Kumari

Ravenshaw University

Darpa Saurav Jyethi

Indian Statistical Institute North-East Centre at Tezpur

Umesh Chandra Naik ( $\nabla$ umeshbiology@gmail.com )

Ravenshaw University https://orcid.org/0000-0001-6456-2449

\section{Research Article}

Keywords: Fertilizer industry, Heavy metals, Bacteria, Chromate reductase, Antioxidants, Detoxification

Posted Date: July 28th, 2021

DOl: https://doi.org/10.21203/rs.3.rs-351917/v1

License: (c) (i) This work is licensed under a Creative Commons Attribution 4.0 International License.

Read Full License

Version of Record: A version of this preprint was published at Archives of Microbiology on August 17th, 2021. See the published version at https://doi.org/10.1007/s00203-021-02523-z. 


\section{Abstract}

The effluent generated from fertilizer plants in Paradeep in the coast of the Bay of Bengal is the major pollutant causing health hazard in the vicinity of the area with respect to plants, animals and microbes. Samples of effluent were found to contain heavy metals ( $\left.\mathrm{mg} \mathrm{L}^{-1}\right)$ : $\mathrm{Cr}(100), \mathrm{Ni}(36.975), \mathrm{Mn}$ (68.673), Pb (20.133), $\mathrm{Cu}$ (74.44), Zn (176.716), $\mathrm{Hg}$ (5.358) and As (24.287) as analyzed by XRF. Indigenous bacterial strains were screened for chromate and multi-metal resistance to remediate the toxic pollutants. The isolated strain G1 was identified as Serratia sp. through 16S-rDNA sequence homology. Potent strain Serratia sp. GP01 treated with $100 \mathrm{mg} \mathrm{L}^{-1}$ of $\mathrm{K}_{2} \mathrm{Cr}_{2} \mathrm{O}_{7}$ has shown the efficacy of reducing $69.05 \mathrm{mg} \mathrm{L}^{-1}$ of Cr over $48 \mathrm{~h}$ of incubation. Further, presence of chromate reductase gene (ChR) in Serratia sp. confirmed the enzymatic reduction of $\mathrm{Cr}(\mathrm{VI})$. SEM-EDX and SEM mapping analysis revealed substantial biosorption of $\mathrm{Cr}$ and other heavy metals present in effluent by Serratia sp. GP01. Antioxidant enzymes such as catalase $\left(72.15 \mathrm{U} \mathrm{mL}^{-1}\right)$, SOD $\left(57.14 \mathrm{U} \mathrm{mL}^{-1}\right)$ and peroxidase $\left(62.49 \mathrm{U} \mathrm{mL}^{-1}\right)$ were found to be higher as compared to the control condition. FTIR study also revealed the role of $\mathrm{N}-\mathrm{H}, \mathrm{O}-\mathrm{H}, \mathrm{C}=\mathrm{C}, \mathrm{C}-\mathrm{H}, \mathrm{C}-\mathrm{O}$, C-N, and $\mathrm{C}=\mathrm{O}$ functional groups of the cell surface of Serratia sp. treated with $\mathrm{K}_{2} \mathrm{Cr}_{2} \mathrm{O}_{7}$ and effluent from the fertilizer industry. Isolated strain Serratia sp. could be used for the detoxification of $\mathrm{Cr}(\mathrm{VI})$ and other heavy metals in fertilizer plant effluent.

\section{Introduction}

The fertilizer industry is one of the most polluting industries across the world. The fertilizer industry, mainly phosphate fertilizer plants are known to be a source of heavy metals and radionuclides (Khater 2012). Inorganic fertilizers such as calcium superphosphate, urea, iron sulphate and copper sulphate contain a high concentration of $\mathrm{Zn}, \mathrm{Co}, \mathrm{Cu}, \mathrm{Cd}, \mathrm{Pb}, \mathrm{Ni}, \mathrm{Fe}, \mathrm{Mn}$, which lead to deterioration of biological diversity of agricultural soil (Gimeno-Garcia et al. 1996). Heavy metals like $\mathrm{Cd}$, $\mathrm{Pb}$, and $\mathrm{As}$ have been found in phosphate fertilizers causing health hazard to plants, animals and microorganisms in surrounding ecosystems (Morgan 2013). Metal induced oxidative stress is created in living organisms due to the generation of reactive oxygen species like $\mathrm{O}^{2-}, \mathrm{OH}$; and $\mathrm{H}_{2} \mathrm{O}_{2}$ leading to the damage of lipid, protein and genomic content (Choudhary et al. 2007). Chromium is one of the most potent mutagenic and carcinogenic elements released by fertilizer industries. The toxic effect of hexavalent chromium [Cr $(\mathrm{VI})]$ is attributed to the high solubility prosperity of $\mathrm{Cr}(\mathrm{VI})$ as it can easily seep into the groundwater. $\mathrm{Cr}$ (VI) can easily pass through the semi-permeable biological membrane and interacts with nucleic acid and cellular proteins of living organisms (Sultan and Hasnain 2005). Due to extreme toxic nature of soluble $\mathrm{Cr}$ $(\mathrm{VI})$, it not only causes a mutational effect but also is carcinogenic in nature due to its strong oxidizing nature (Mclean et al. 2000; Camargo et al. 2003). High concentration $\mathrm{Cr}(\mathrm{VI})$ causes harm to biological systems by damaging the cell membrane, disrupting the cellular function, alteration in the specificity of enzymes and damaging the DNA structure (Bagchi et al. 2002). $\mathrm{Cr}(\mathrm{VI})$ causes various diseases like dermatitis, diarrhea, ulcers, eye, bronchial carcinomas and skin irritation, kidney dysfunction and probably lung carcinoma (Baruthio 1992). Exposure to $\mathrm{Cr}$, $\mathrm{Cd}$ and $\mathrm{Zn}$ concentrations also results in cancer, gastrointestinal and respiratory damage, damages to the heart, brain, and kidney. 
Various conventional methods including precipitation, ion exchange and adsorption on coal and activated carbon are employed for the removal of toxic chromium from environment. These methods require high energy and could not address the detoxification of toxic chromium (Avudainayagam et al. 2003). There are reports on various bacterial species as $\mathrm{Cr}(\mathrm{VI})$ reducing bacteria such as Bacillus sp. (Elangovan et al. 2006; Das et al. 2014) Microbacterium (Pattanapipitpaisal et al. 2001), Ochrobactrum intermedium (Faisal and Hasnain 2004), Pseudomonas sp. (Rajkumar et al. 2005), Shewanella oneidensis MR-1 (Thompson et al. 2007), Arthrobactersp., Microbacterium sp. (Gutierrez et al. 2010). The detoxification strategies include bio-sorption, bioaccumulation and bioreduction by enzymatic reduction (Ramirez-Diaz et al. 2008). Microbial detoxification of $\mathrm{Cr}(\mathrm{VI})$ has been identified since the 1970s, which seems to be cost-effective and eco-friendly approach over conventional methods (Camargo et al. 2003). A wide group of $\mathrm{Cr}(\mathrm{VI})$ resistant bacterial species such as Pseudomonas sp. (Rajkumar et al. 2005), Shewanella oneidensis MR-1 (Thompson et al. 2007), Arthrobacter sp., Microbacterium sp. (Gutierrez et al. 2010), Bacillus sp. (Das et al. 2014) have strong chromium metabolising pathway. Extracellular, intracellular and membrane bound reductases are involved in the reduction of $\mathrm{Cr}(\mathrm{VI})$ into $\mathrm{Cr}$ (III) (Joutey et al., 2015). Reductases such as aldehyde oxidase, cytochrome p450, DT-diaphorase (Patra, et al. 2010), nitroreductase (Kwak et al., 2003) are involved in resistance and detoxification of $\mathrm{Cr}(\mathrm{VI})$. Reports on different chromate resistant genes (chrR, chrB, chrA, chrC, chrF, ruvB and chr2) from various bacteria like Pseudomonas aeruginosa, Ochrobactrum tritici, Ralstonia metallidurans, responsible for resistance to chromate ion and other toxic metalloids by minimizing the oxidative stress in the bacterial system along with the efflux system have been published (Juhnke et al. 2002; Aguilar-Barajas et al. 2008; Gadd 2010; Morais et al. 2011).

The effluent from the fertilizer industry is discharged into water bodies channeled to Mahanadi River near the confluence point in the Bay of Bengal. As a result, the aquatic system of river Mahanadi near Paradeep is polluted which in turn affects the nearby ecosystems causing health effects on humans, animals and plants as well. The untreated acidic effluent from the fertilizer plants is mainly responsible for increasing ammonia, nitrogen and phosphorous concentration. The effluent of fertilizer industries containing toxic heavy metals including carcinogenic chromium aggravates the pollution menace in surrounding regions of the port town of Paradeep, off the coast of the Bay of Bengal. Given this pollution problem, the present study attempts to address the removal and detoxification of $\mathrm{Cr}(\mathrm{VI})$ present in the effluent. We have investigated the potency of an indigenous chromate resistant bacterium (strain-GP01) which could be used for successful bioremediation of $\mathrm{Cr}(\mathrm{VI})$ and other heavy metals in effluent released from fertilizer industries.

\section{Materials And Methods}

\section{Sampling site}

Effluent sample was collected from the site $(20.262646,86.630084)$ in the Paradeep region, Odisha. Side location map is depicted in fig. 1. Sterile bottles were used for sampling and collected samples were 
brought to the laboratory in ice packs. $\mathrm{pH}$, redox potential and temperature parameters were recorded during sampling by pocket $\mathrm{pH}$ meter (Hanna) and mercury thermometer respectively.

\section{Elemental analysis by ED-XRF}

The elemental composition of effluent was analyzed by the X-ray fluorescence (ED-XRF) spectrometry method (PANalytical Epsilon 5, Bruker S4 PIONEER, Europe) at Advanced Instrumentation Research Facility (AIRF), JNU, New Delhi.

\section{Isolation of bacterial strains}

About $1 \mathrm{~mL}$ of sample was taken and diluted up to $10 \mathrm{~mL}$ with double-distilled water in a test tube as stock solution. A dilution series was prepared with different dilution factors ranging from $10^{-1}$ and $10^{-6}$ for isolation of bacterial strains from the samples. Diluted samples $(100 \mu \mathrm{L})$ were spread onto the nutrient agar petri-dishes (agar-agar 1.8, peptone 1.0, yeast extract 1.0, sodium chloride $1.0 \mathrm{~g} \mathrm{~L}^{-1}$ ) and incubated in a microbiological incubator (SDS1-2S, Smita Scientific) at $37^{\circ} \mathrm{C}$ for $24 \mathrm{~h}$ to $48 \mathrm{~h}$ for the growth of bacteria. Based on the morphological features such as size, colour, texture, the bacterial strains were isolated into different morphological communities.

\section{Screening and growth pattern of isolates strains under $\mathrm{K}_{2} \mathrm{Cr}_{2} \mathrm{O}_{7}$ stress}

The isolated bacterial strains were inoculated in Minimal Salt Media (MSM) amended with $50 \mathrm{mg} \mathrm{L}^{-1}$ to $500 \mathrm{mg} \mathrm{L}^{-1}(\mathrm{v} / \mathrm{v})$ of potassium dichromate $\left(\mathrm{K}_{2} \mathrm{Cr}_{2} \mathrm{O}_{7}\right)$ and incubated at $35^{\circ} \mathrm{C}$ for 3 days at $100 \mathrm{rpm}$. The growth pattern of bacterial isolate in liquid media was calculated by measuring OD at $600 \mathrm{~nm}$ (Naik et al. 2012).

\section{Molecular identification of potent chromium resistance bacteria}

Genomic DNA was isolated from the potent chromium resistance bacteria strain (G1) by QIAamp DNA Mini Kit from Qiagen. The 16S rDNA was amplified using primer sets of forward primer 27F (5'-AGAGTTT GATCMTGGCTCAG-3') and the reverse primer 1492R (5'-CGGTTACCTTGTTACGACTT-3'). The PCR reaction mixture of $25.0 \mu \mathrm{L}$ contains $0.5 \mu \mathrm{M}$ of each primer, Taq Buffer (1X), $1.5 \mathrm{mM}$ of $\mathrm{MgCl}_{2}, 500 \mu \mathrm{M}$ of DNTP's mix, $1 \mathrm{U}$ of Taq polymerase and $50 \mathrm{ng}$ of template DNA. The DNA profiling was carried out by using a thermal cycler (Veriti-96, Applied Biosystems, USA) with the following programs: pre-heating at $94^{\circ} \mathrm{C}$ for $3 \mathrm{~min}, 35 \mathrm{cycles}$ of denaturation at $94^{\circ} \mathrm{C}$ for $30 \mathrm{sec}$, primer annealing at $50^{\circ} \mathrm{C}$ for $30 \mathrm{sec}$, elongation at $72^{\circ} \mathrm{C}$ for $90 \mathrm{sec}$ and final extension step at $72^{\circ} \mathrm{C}$ for $5 \mathrm{~min}$. Amplified PCR products were purified by using the HiPurA PCR product purification kit from Himedia. The purified PCR amplified product (approximately 1500bp) was used for 16SrDNA sequencing with Genetic Analyser-3500 (Applied Biosystems, USA), using BDT v3.1 ready reaction mixture. The sequences were assembled and compared with nucleotide BLAST search, by using the existing gene bank database, National Center for Biotechnology Information (NCBI) and EzBioCloud database (Kim et al. 2012). Corresponding neighbor sequences (Based upon maximum similarity and zero E-value) were downloaded from the NCBI database 
and valid type strains from the EZBioCloud database. The phylogenetic tree was constructed by aligning the sequences and bootstrapped neighbor-joining relationships (1000 replicates) with MEGA version 7.0 software (Stackebrandt and Goebel 1994; Tamura et al. 2013; Kumar et al. 2016).

\section{Identification of chromate reductase in Serratia sp. GP01}

Bacterial chromate reductase genes ( $C h R$ and $C h r T$ ) were amplified with the genomic DNA of Serratia sp. GP01. PCR amplification of ChR and ChrT genes was carried out in the thermal cycler (Veriti-96, Applied Biosystems, USA), by using the primer sets as given in the table 2 (Patra et al. 2010; Zhou et al. 2017). A total volume of $25.0 \mu \mathrm{L}$ PCR reaction mixture containing $0.5 \mu \mathrm{M}$ of each primer, $11.0 \mu \mathrm{L}$ of $2 \mathrm{X}-\mathrm{PCR}$ TaqMixture (Himedia), $50 \mathrm{ng}$ of template DNA. Final volume was brought with molecular grade water. PCR workflow was set as following programs: pre-heating at $94^{\circ} \mathrm{C}$ for $5 \mathrm{~min}, 35$ cycles of denaturation at $94^{\circ} \mathrm{C}$ for $30 \mathrm{sec}$, primer annealing at $53^{\circ} \mathrm{C}$ (for $\mathrm{ChR}$ ) and $56^{\circ} \mathrm{C}$ (for $\mathrm{ChrT}$ ) for $30 \mathrm{sec}$, elongation at $72^{\circ} \mathrm{C}$ for $60 \mathrm{sec}$ and final extension step at $72^{\circ} \mathrm{C}$ for $10 \mathrm{~min}$. Amplified PCR products were separated on $2 \%(\mathrm{w} / \mathrm{v})$ agarose gel and purified by using the HiPurA-PCR product purification kit (Himedia). The purified PCR product was used for sequencing with Genetic Analyser-3500 (Applied Biosystems, USA), using BDT v3.1 ready reaction mixture. An identified nucleotide sequence of the amplified chromate reductase gene was translated and appropriate open reading fame was selected by employing ExPASy tools (http://www.expasy.org/tools/dna.html). Translated chromate reductase was searched in ExPASy-blast search (https://web.expasy.org/blast/) and chromate reductase sequences of different Serratia sp. were retrieved from $\mathrm{NCBI}$. Based on homology similarity, a phylogenetic tree was prepared by aligning the sequences in Clustal W and tree was constructed by using MEGA 7.0 with neighbor-joining method (1000 bootstrap replicates at $50 \%$ ) (Tamura et al. 2007). Significant alignment of the query sequence of Serratia sp. GP01 with another group of bacteria was carried out by NCBI blastp (https://blast.ncbi.nlm.nih.gov/Blast.cgi) and similarities of sequences were analyzed.

Table 2 Details of the primers used for the amplification of chromate reductase genes.

\begin{tabular}{|c|c|c|c|}
\hline Chromate reductase & & Primers/Oligos sequence $\left(5^{\prime}-3^{\prime}\right)$ & Reference \\
\hline \multirow[t]{2}{*}{ ChR } & Forward & TCACGCCGGAATATAACTAC & \multirow[t]{2}{*}{ Patra et al. 2010} \\
\hline & Reverse & CGTACCCTGATCAATCACTT & \\
\hline \multirow[t]{2}{*}{ ChrT } & Forward & ATCATGTCAGATACCTTGAAAGTGG & \multirow[t]{2}{*}{ Zhou et al. 2017} \\
\hline & Reverse & TGCTTTAACCCGCCGAATATA & \\
\hline
\end{tabular}

\section{Removal of Chromium by isolated potent strain Serratia sp. GP01}


$\mathrm{Cr}(\mathrm{VI})$ removal potential of Serratia sp. GP01 was measured by inoculating the bacterial isolates in liquid glucose media containing fertilizer industry effluent. Bacteria culture and un-inoculated culture medium (control) were incubated in an orbital shaker incubator at $120 \mathrm{rpm}$ and $30^{\circ} \mathrm{C}$. Reduction of $\mathrm{Cr}(\mathrm{VI})$ in the medium was assayed by diphenylcarbazide (DPC) method. About $1 \mathrm{~mL}$ of sample was collected after 24 $\mathrm{h}, 48 \mathrm{~h}$ and $72 \mathrm{~h}$ followed by centrifugation at $12000 \times \mathrm{g}$ for $10 \mathrm{~min}$ at $4^{\circ} \mathrm{C}$. Then about $1 \mathrm{~mL}$ of diphenylcarbazide solution ( $0.25 \mathrm{gm}$ diphenylcarbazide dissolved in $100 \mathrm{ml}$ acetone) was added to the collected supernatant in a test tube followed by the addition of one drop of phosphoric acid to lower the $\mathrm{pH}$. Then the solution was allowed to keep at room temperature for the development of colour for 5 min and the concentration of $\mathrm{Cr}(\mathrm{VI})$ was estimated by spectrophotometer at $540 \mathrm{~nm}$ (Zahoor and Rehman 2009). The $\mathrm{Cr}(\mathrm{VI})$ reduction was estimated by the following equation:

$\mathrm{Cr}(\mathrm{VI})$ reduction $(\%)=\mathrm{A}-\mathrm{B} / \mathrm{A} \times 100$

Where, A and B refers to initial concentration and residual concentration respectively.

\section{Antioxidant Assay}

Equal volume $(10 \mathrm{~mL})$ of effluent treated and untreated bacteria culture were centrifuged at $10000 \times \mathrm{g}$ for $10 \mathrm{~min}$ at $4^{\circ} \mathrm{C}$. Bacterial pellet were resuspended in $1 \mathrm{~mL}$ of lysis buffer [ $100 \mathrm{mM}$ Tris-HCl (pH 8.0), $2 \mathrm{mM}$ $\mathrm{MgCl}_{2}, 0.1 \mathrm{mM}$ EDTA Na $2,0.2 \mathrm{M} \mathrm{NaCl}, 1 \%$ Triton $\mathrm{x}-100$ ] followed by sonication (Vibra-m-Cell, Sonic, USA) at $50 \%$ amplitude ( $30 \mathrm{kHz}$ frequency rate) with $5 \mathrm{sec}$ on and $5 \mathrm{sec}$ off for $15 \mathrm{cycles}$ at $4^{\circ} \mathrm{C}$. The lysate was spun in a pre-chilled centrifuge for $15 \mathrm{~min}$ at $20000 \times \mathrm{g}$ and $4^{\circ} \mathrm{C}$ (Zhang et al. 2013). Bacterial crude extracts were estimated by Bradford (1976) assay. Antioxidant enzymes such as superoxide dismutase, catalase and peroxidase were carried out to assess the resistance of Serratia sp. GP01 against toxicity effect of fertilizer industry effluent. Catalase activity was measured in bacterial extract with the methods developed by Aebi (1984). Bacterial extract of $20 \mu \mathrm{L}$ was mixed with $980 \mu \mathrm{L}$ of $\mathrm{H}_{2} \mathrm{O}_{2}$ buffer and absorption was measured at $240 \mathrm{~nm}$ using a UV-vis spectrophotometer for $60 \mathrm{sec}$ at interval of $15 \mathrm{sec}$. The activity was calculated by decrease in absorbance of $\mathrm{H}_{2} \mathrm{O}_{2}$ at $240 \mathrm{~nm}$ concerning time intervals. Peroxidase activity was measured in bacterial crude extract according to the method of Chance and Maehly (1955). The reaction mixture contains $350 \mu \mathrm{L}$ of $5 \%(\mathrm{w} / \mathrm{v})$ pyrogallol in $100 \mathrm{mM}$ potassium phosphate buffer at pH 6 and $25 \mu \mathrm{L}$ of bacteria cell lysate. Blank contains the reaction mixture and $25 \mu \mathrm{L}$ of un-inoculated media. The reaction was initiated by the addition of $0.5 \%(\mathrm{v} / \mathrm{v})$ of hydrogen peroxide $30 \%$ solution and absorption was measured at $420 \mathrm{~nm}$ using UV-VIS spectrophotometer per $34 \mathrm{sec}$ at $25^{\circ} \mathrm{C}$. SOD activity was also measured in bacterial extract using the protocol as suggested by Ewing and Janero (1995). In this assay, $25 \mu \mathrm{L}$ of bacterial extract was mixed with $20 \mu \mathrm{L}$ of reaction buffer [ $50 \mathrm{mM}$ phosphate buffer, $0.1 \mathrm{mM}$ EDTA, $98 \mu \mathrm{M}$ NADH, and $62 \mu \mathrm{M}$ NBT, pH 7.4]. The reaction was initiated by adding $20 \mu \mathrm{L}$ of an initiating reagent ( $50 \mathrm{mM}$ phosphate buffer and $33 \mu \mathrm{M}$ PMS in $0.1 \mathrm{mM}$ EDTA, pH 7.4). The SOD activity was calculated by measuring the absorbance at $560 \mathrm{~nm}$.

\section{Scanning Electron Microscope and EDX Analysis}


Bacterial cells were fixed in $1 \%(\mathrm{v} / \mathrm{v})$ of glutaraldehyde and $2 \%(\mathrm{v} / \mathrm{v})$ paraformaldehyde buffered with 0.1 $\mathrm{M}$ of sodium phosphate buffer saline $(\mathrm{pH} 6.8)$ for $12-18 \mathrm{~h}$ at $4^{\circ} \mathrm{C}$ followed by washing with fresh buffer and fixation with osmium tetraoxide $(1 \%)$ in the same buffer at $4^{\circ} \mathrm{C}$ for $2 \mathrm{~h}$. Fixed bacterial cells were washed with phosphate buffer followed by dehydration in a series of ethanol-water solution $(30 \%, 50 \%$, $70 \%$ and $90 \%$ ethanol) for 5 min each and kept for drying under a $\mathrm{CO}_{2}$ atmosphere for $20 \mathrm{~min}$. Bacterial cells were mounted with aluminium stubs and were coated with $90 \AA$ thick gold palladium (VG Microtech, East Sussex, TN22, England) for $30 \mathrm{~min}$. Coated bacterial cells were viewed at $15 \mathrm{kV}$ with SEM (ModelZeiss EVO40). Energy-dispersive X-ray spectrometer (EDAX, USA) was run at $20 \mathrm{kV}$ for studying the biosorption of chromium by isolated strain (Naik et al. 2012; Sahoo et al. 2020).

\section{FTIR Analysis on functional groups}

Fourier Transform Infrared Spectroscopy (FTIR) was used to identify the changes in functional groups of bacteria under different stress conditions. Both control and experimental (10\% effluent and $100 \mathrm{mg} \mathrm{L}^{-1}$ of $\left.\mathrm{K}_{2} \mathrm{Cr}_{2} \mathrm{O}_{7}\right)$ bacterial biomass were harvested at exponential phase $\left(A^{600}=0.6\right)$. The biomass was dried in a hot air oven at $60^{\circ} \mathrm{C}$ for complete dryness and cool in a desiccator. Approximately $5 \mathrm{mg}$ of dried biomass was made to a fine powder along with $50 \mathrm{mg}$ of potassium bromide, using an agate mortar and pestle (Thomas Scientific), (Kowalczuk and Pitucha 2019). The powdered samples were pressed and KBr pellets were prepared for analysis. The infrared spectra (\%T) were recorded by using a Spectrum RX I Perkin Elmer, FTIR Spectrometer (Thermo scientific), within the range 400 to $4000 \mathrm{~cm}^{-1}$.

\section{Results And Discussion}

\section{Elemental analysis of effluent}

Elemental analysis of effluent from the fertilizer industry revealed the presence of heavy metals $\left(\mathrm{mg} \mathrm{L}^{-1}\right)$ : $\mathrm{Cr}$ (100), Ni (36.975), Mn (68.673), Pb (20.133), Cu (74.44), Zn (176.716), Hg (5.358) and As (24.287) as analyzed by XRF analysis shown in table 1 . The effluent was found to be highly acidic in nature with the $\mathrm{pH}$ (1.36) and redox potential (289). Report published by Institute of Minerals and Materials Technology (IMMT) shows the presence of different heavy metals beyond the permissible limits (Dharmendra et al. 2020) at the Paradeep region. Previous studies have also confirmed the existence of heavy metals such as $\mathrm{Cd}, \mathrm{Co}, \mathrm{Cu}, \mathrm{Ni}, \mathrm{Pb}, \mathrm{Zn}, \mathrm{Fe}$ and $\mathrm{Mn}$ in different inorganic fertilizers like urea, calcium superphosphate, iron sulphate and copper sulphate (Gimeno-Garcia et al. 1996). Further, Mekki and Sayadi (2017) have reported that the heavy metal accumulation increased over time in phosphate fertilizer treated soil samples with average values in the following order: iron $\left(\right.$ Fe $\left.252.72 \mathrm{mg} \mathrm{L}^{-1}\right)>\operatorname{Zinc}\left(\mathrm{Zn} 152.95 \mathrm{mg} \mathrm{L}^{-1}\right)>$ Lead $\left(\mathrm{Pb} 128.35 \mathrm{mg} \mathrm{L}^{-1}\right)>$ Copper $\left(\mathrm{Cu} 116.82 \mathrm{mg} \mathrm{L}^{-1}\right)>$ Cadmium (Cd $\left.58.03 \mathrm{mg} \mathrm{L}^{-1}\right)$.

Table 1 XRF elemental analysis of fertilizer industry effluent at Paradeep, India. 


\begin{tabular}{|llll|}
\hline Compound & Corr. (cps/mA) & Conc. & Unit \\
\hline $\mathrm{P}$ & 10.134 & 1.170 & $\%$ \\
\hline $\mathrm{S}$ & 1.705 & 0.292 & $\%$ \\
\hline $\mathrm{Cl}$ & 0.520 & 377.390 & $\mathrm{ppm}$ \\
\hline $\mathrm{K}$ & 1.971 & 404.017 & $\mathrm{ppm}$ \\
\hline $\mathrm{Ca}$ & 66.262 & 0.985 & $\%$ \\
\hline $\mathrm{V}$ & 0.576 & 113.599 & $\mathrm{ppm}$ \\
\hline $\mathrm{Cr}$ & 0.907 & 100.285 & $\mathrm{ppm}$ \\
\hline $\mathrm{Mn}$ & 0.981 & 68.673 & $\mathrm{ppm}$ \\
\hline $\mathrm{Fe}$ & 19.567 & 971.749 & $\mathrm{ppm}$ \\
\hline $\mathrm{Ni}$ & 0.730 & 36.955 & $\mathrm{ppm}$ \\
\hline $\mathrm{Cu}$ & 3.090 & 74.444 & $\mathrm{ppm}$ \\
\hline $\mathrm{Zn}$ & 8.055 & 176.716 & $\mathrm{ppm}$ \\
\hline $\mathrm{As}$ & 2.230 & 24.287 & $\mathrm{ppm}$ \\
\hline $\mathrm{Se}$ & 0.000 & 0.000 & $\mathrm{ppm}$ \\
\hline $\mathrm{Sr}$ & 3.959 & 155.732 & $\mathrm{ppm}$ \\
\hline $\mathrm{Zr}$ & 0.234 & 6.581 & $\mathrm{ppm}$ \\
\hline $\mathrm{W}$ & 13.275 & 925.007 & $\mathrm{ppm}$ \\
\hline $\mathrm{Hg}$ & 0.129 & 5.358 & $\mathrm{ppm}$ \\
\hline $\mathrm{Pb}$ & 0.732 & 20.133 & $\mathrm{ppm}$ \\
\hline
\end{tabular}

\section{Growth pattern of isolates strain under $\mathrm{K}_{2} \mathrm{Cr}_{2} \mathrm{O}_{7}$ stress}

The bacterial population was analyzed from the effluent site near to fertilizer industry located at Paradeep, Odisha, India. Samples exhibited different number and pattern of colonies on pour plate culture incubated for $24 \mathrm{~h}$ at $37^{\circ} \mathrm{C}$. Based on the morphological features such as size, colour, texture, the bacterial strains were isolated into different morphological communities. Bacterial isolates G1 and G2 incubated in MSM amended with 50 to $500 \mathrm{mg} \mathrm{L}^{-1}$ of $\mathrm{K}_{2} \mathrm{Cr}_{2} \mathrm{O}_{7}$, have shown contrasting growth pattern over an incubation period of $72 \mathrm{~h}$. Strain $\mathrm{G} 1$ has shown a higher growth rate as compared to $\mathrm{G} 2$ after 24 h, $48 \mathrm{~h}$ and $72 \mathrm{~h}$ of incubation period than strain G2. It was observed that G1 strain showed high growth 
in media enriched with 50 and $100 \mathrm{mg} \mathrm{L}^{-1}$ of $\mathrm{K}_{2} \mathrm{Cr}_{2} \mathrm{O}_{7}$ and decreased growth was found in culture media enriched with $250,500 \mathrm{mg} \mathrm{L}^{-1}$ over $72 \mathrm{~h}$ (Fig. 2). The growth of the isolated bacterial strain was found to decrease with an increasing $\mathrm{K}_{2} \mathrm{Cr}_{2} \mathrm{O}_{7}$ concentration. Phospho-gypsum is the major by-products of phosphate fertilizer industry effluent which contains toxic metals like $\mathrm{Cd}, \mathrm{Cr}, \mathrm{Hg}, \mathrm{Pb}, \mathrm{As}, \mathrm{Zn}$ and a few radioactive elements like uranium and thorium (Khater 2012). Apart from that, $\mathrm{pH}$ is an important factor as all the chemical reactions of aquatic bodies are controlled by $\mathrm{pH}$. The water sample collected from the effluent site was found to have a pH of 1.35 at a temperature of $29.6^{\circ} \mathrm{C}$. The toxicity of heavy metals could be further enhanced by lower $\mathrm{pH}$.

The strain $\mathrm{G} 1$ has a greater population of $21 \times 10^{2} \mathrm{cfu} \mathrm{mL}^{-1}$ than strain $\mathrm{G} 2$ having $11 \times 10^{2} \mathrm{cfu} \mathrm{mL}^{-1}$. The result shows that strain $\mathrm{G} 1$ has potential resistance and a high growth rate in comparison to strain $\mathrm{G} 2$ against toxicity of heavy metals present in the effluent. Previous report has also suggested that increasing concentration of heavy metals is attributed to decreased $\mathrm{cfu} \mathrm{mL}^{-1}$ of microbial groups. Alterations in the composition of microbial communities could be taken as the indicator of anthropogenic and industrial effects on soil and water ecosystems (Ashok et al. 2011). The toxic effects of heavy metals result mainly from the interaction of metals with proteins (enzymes) and inhibition of metabolic processes in the bacterial cell. The isolated strains might have a high resistance and detoxifying capacity as they are indigenous to that environmental condition.

\section{Molecular identification of potent bacterial strain}

A sequence of amplified genomic DNA of potent bacterial strain G1 was compared with the existing database of the gene bank, National Centre for Biotechnology Information (NCBI). The bootstrap consensus sequence was drawn with the neighbour-joining multiple sequences alignment method using software mega version 7.0 with different species of bacteria. The isolated strain has shown $99 \%$ sequence similarity with the 16S rDNA sequence of the corresponding sequences of Serratia sp. and hence the selected strain was identified as Serratia sp. GP01 (Accession number: MH971240) (Fig. 3).

\section{Analysis of chromate reductase genes in Serratia sp. GP01}

The result of PCR amplified products on agarose gel (supplementary figure 1) has shown the presence of chromate reductase gene $(C h R)$ in Serratia sp. GP01. Partially amplified chromate reductase $(C h R)$ gene product was about $268 \mathrm{bp}$ long. Phylogenetic analysis of partially identified chromate reductase gene $(C h R)$ with other groups of bacteria is shown in figure 4. Chromate reductase (ChR) of strain GP01 (query) has shown close relationship with Class-I_chromate reductase_flavoprotein, putative NADPH dependent FMN reductase, flavin reductase of E. coli, chromate reductase of Bacillus sp., and other groups of bacteria including, Shigella sonnei, Enterobacteriaceae bacterium, Shigella flexneri, Trichuris trichiura. However, ChR of Serratia sp. GP01 and chromate reductases of other Serratia sp. strains were found to be distantly related. Multiple alignments of different chromate reductase through NCBI blastp (https://blast.ncbi.nlm.nih.gov/Blast.cgi) has shown the amino acid similarity matches with other groups of bacteria (Supplementary figure 2). In the present study nucleotide sequences of chromate reductase 
gene $(C h R)$ as analyzed by sequencing followed by ExPASy analysis was submitted to NCBI (GenBank) under the accession number (MZ476040). Aguilar-Barajas et al (2008) have reported the ChrR gene from Pseudomonas aeruginosa which is responsible for chromate resistance. Kalsoom et al. (2021) have also reported the presence of chromate resistance genes (ChrR) from Staphylococcus simulans against chromate toxicity. It was evident that in the present study, the identified potent strain GP01 has the chromate reductase gene $(C h R)$, which helps in the reduction of the $\mathrm{Cr}(\mathrm{VI})$ and helps the bacteria to withstand the extreme toxic conditions.

\section{Removal of Chromium by Serratia sp. GP01}

The selected bacterial isolate $\mathrm{G} 1$ exhibit different $\mathrm{Cr}(\mathrm{VI})$ reduction potency at $100 \mathrm{mg} \mathrm{L}^{-1}$ concentration under different incubation times in the liquid media. Growth of the isolated strain-G1 (Serratia sp. GP01) was found to be higher in $100 \mathrm{mg} \mathrm{L}^{-1}$ concentration of chromium and it showed maximum reduction capacity of $62.43 \mathrm{mg} \mathrm{L}^{-1}, 69.05 \mathrm{mg} \mathrm{L}^{-1}, 52.62 \mathrm{mg} \mathrm{L}^{-1}$ after $24 \mathrm{~h}, 48 \mathrm{~h}$ and $72 \mathrm{~h}$ of incubation respectively (Fig. 5). Serratia sp. Cr-10 has shown $\mathrm{Cr}(\mathrm{VI})$ reduction activity with the highest reduction rate of $0.28 \mathrm{mg}$ $\mathrm{L}^{-1} \mathrm{~h}^{-1}$, lower than Brucella sp. (0.92 $\mathrm{mg} \mathrm{L}^{-1} \mathrm{~h}^{-1}$ ) (Thacker et al. 2007) and Pseudomonas sp. (0.24 mg $\mathrm{L}^{-1} \mathrm{~h}^{-1}$ ) (McLean et al. 2000). In the present study, the isolated strain Serratia sp. GP01 showed high chromium reduction capacity in comparison to the above mentioned strains reported by different authors. It could be suggested that isolated Serratia sp. GP01 could be used for detoxification of $\mathrm{Cr}(\mathrm{VI})$ present in effluent from fertilizer industries.

\section{Antioxidants Production by Serratia sp. GP01}

Bacterial crude extract protein samples were estimated to be $2.1 \mathrm{mg} \mathrm{mL}^{-1}$. The assay of bacterial strain G1 (Serratia sp. GP01) with 10\% (v/v) heavy metals showed a distinct effect of fertilizer industry effluent on superoxide dismutase (SOD), catalase and peroxidase activity (Fig. 6). Increased activity of catalase $\left(72.15 \mathrm{U} \mathrm{mL}^{-1}\right)$, SOD $\left(57.14 \mathrm{U} \mathrm{mL}^{-1}\right)$ and peroxidase $\left(62.49 \mathrm{U} \mathrm{mL}^{-1}\right)$ in Serratia sp. GP01 are noticed in response to $10 \%(\mathrm{v} / \mathrm{v})$ of effluent from fertilizer idustry. Heavy metal induced oxidative stress due to the generation of free radicals enhance the accumulation and activity of detoxifying enzymes (llias et al. 2011). Under normal circumstances, the concentration of free radicals remain low due to the activity of protective enzymes which includes SOD, catalase, peroxidase etc. The expressions of these enzymes are thought to be increased under heavy metals stress to detoxify the reactive oxygen species (Choudhary et al. 2007). An earlier study has shown that the first line of defense against the generation of toxic oxygen species in the induction of SOD activity (Lenartova et al. 1998). Previous study has also reported that hydrogen peroxide may also be involved in peroxidase mediated reaction of oxidative polymerization strengthening cell wall and formation of barrier anti-stress structures (Cosgrove 1997).

\section{Bacterial morphology under heavy metals stress}

Morphological assessment and quantification of chromium and other heavy metals absorbed on the surface of isolated bacterial biomass were performed by scanning electron microscopy (SEM) and energy 
dispersive X-ray analysis (EDX) analysis. $\mathrm{K}_{2} \mathrm{Cr}_{2} \mathrm{O}_{7}$ treated bacterial strain Serratia sp. GP01 showed morphological changes. Untreated bacterial strain was rod-shaped and elongated having a smooth surface whereas $\mathrm{K}_{2} \mathrm{Cr}_{2} \mathrm{O}_{7}$ treated bacteria were found to be smaller and irregular and associated with extracellular granules. Effluent treated bacteria have shown drastic changes in morphological features in terms of size and shape like drum (Fig. 7). The changes in cell morphology in response to fertilizer industry effluent might be due to the cumulative toxicity of different heavy metals present in the effluent. The interaction of toxicity of different heavy metals could be the possible factor for creating a highly toxic condition for the isolated bacterial strain (Naik et al. 2012; Jin et al. 2017). Changes in surface morphological features such as roughness, size, shape, and swelling have also been reported on bacteria Bacillus cereus IST105, Bacillus subtilis and Escherichia coli in response to chromium toxicity. Bacterial cells may arrange themselves as groups to reduce exposure to chemicals and this might be the one of the adoptive mechanisms for many microbes (Schembri et al. 2003; Naik et al. 2012; Samuel et al. 2013).

\section{SEM-EDX for $\mathrm{Cr}$ and metals biosorption}

SEM-EDX analysis clearly showed the metals disintegration and absorption onto the surface of isolated strain. The isolated strain Serratia sp. GP01 showed strong multi-metal absorption potency. EDX analysis revealed that the cells exposed to $\mathrm{K}_{2} \mathrm{Cr}_{2} \mathrm{O}_{7}$ showed the chromium peaks (with $0.13 \mathrm{wt} \%$ ) indicating biosorption of $\mathrm{Cr}$ and precipitation of chromium inside the bacterial cell. The intensity of the biosorbed peak for different heavy metals was based on the concentration of heavy metals as analyzed through EDXRF. The potency and efficiency for biosorption of multi metals could be attributed to the bioreduction of heavy metals through the reductase enzyme. Earlier it has been reported on multi-metal tolerant strain Bacillus cereus FIT10 which could be used for the bioremediation of toxic metals such as $\mathrm{Ni}(\mathrm{II}), \mathrm{Cr}(\mathrm{VI})$, $\mathrm{Pb}$ (II), and $\mathrm{Cu}$ (II) from aqueous solution. (Dhanwal et al. 2018). The biosorption and precipitation of chromium residues on the cell surface of strain Cellulosimicrobium sp. has also been studied by EDX analysis (Bharagava and Mishra 2018).

\section{Study on functional groups}

FTIR analyses of untreated bacteria, $\mathrm{K}_{2} \mathrm{Cr}_{2} \mathrm{O}_{7}$ treated bacteria and $10 \%(\mathrm{v} / \mathrm{v})$ effluent treated bacteria have revealed the status of functional groups as IR spectra pattern are shown in supplementary figure 4 . The wave number $2925 \mathrm{~cm}^{-1}$ attributed to the stretching vibration of $\mathrm{O}-\mathrm{H}$ groups on the surface of untreated bacteria whereas spectra pattern has shown shifting of $0-\mathrm{H}$ group at $2925 \mathrm{~cm}^{-1}$ and $2930 \mathrm{~cm}^{-1}$ in chromium and effluent treated bacteria respectively. Further, the peak at $3416 \mathrm{~cm}^{-1}$ is assigned to stretching of $\mathrm{OH}$ groups which enhance the hydration of bacterial cell while there is shifting of $\mathrm{O}-\mathrm{H}$ at $3424 \mathrm{~cm}^{-1}$ and $3421 \mathrm{~cm}^{-1}$ under $\mathrm{K}_{2} \mathrm{Cr}_{2} \mathrm{O}_{7}$ and $10 \%$ (v/v) effluent respectively. Spectroscopic changes at $1394 \mathrm{~cm}^{-1}$ have shown bending vibration of $\mathrm{C}-\mathrm{H}$ group whereas similar spectroscopic changes at 1402 $\mathrm{cm}^{-1}$ in the group observed in chromium stress condition. Spectroscopic changes at $1397 \mathrm{~cm}^{-1}$ has shown bending vibration of $\mathrm{C}-\mathrm{H}$ group whereas a slight modification in absorbance at $1402 \mathrm{~cm}^{-1}$ was 
observed in stress condition. Shifting of stretching vibration of $\mathrm{N}-\mathrm{H}$ group was observed at $1279 \mathrm{~cm}^{-1}$ and $1235 \mathrm{~cm}^{-1}$ respectively in response to $\mathrm{Cr}(\mathrm{VI})$ and fertilizer industry effluent. A broad band at $1084 \mathrm{~cm}^{-}$

${ }^{1}$ represented the stretching of $C=0$ of amide groups which brought changes at $1057 \mathrm{~cm}^{-1}$ and $1235 \mathrm{~cm}^{-1}$ under chromium and effluent stress respectively.

FTIR spectroscopy is also used for the study of the position and status of functional groups of potent chromate resistant strain Serratia sp. GP01. The wave number $2925 \mathrm{~cm}^{-1}$ attributed to the stretching vibration of $\mathrm{C}-\mathrm{H}$ group on the surface untreated bacteria whereas a higher spectra pattern has shown shifting of $\mathrm{C}-\mathrm{H}$ group at $2930 \mathrm{~cm}^{-1}$ on chromium and effluent treated bacteria. There were changes in the functional group of strain Serratia sp. GP01 after treatment of chromium and 10\% (v/v) effluent over 24 $\mathrm{hr}$ of incubation (supplementary figure 4). The peak at $3416 \mathrm{~cm}^{-1}$ is assigned to stretching $\mathrm{OH}$ groups which enhance the hydration of bacterial cell. A broad band at $1084 \mathrm{~cm}^{-1}$ represented the stretching of $\mathrm{C}=\mathrm{O}$ of amide groups which showed shifting at $1057 \mathrm{~cm}^{-1}$ and $1235 \mathrm{~cm}^{-1}$ under $\mathrm{Cr}(\mathrm{VI})$ and effluent respectively. The phenomenon of absorption on bacterial cell surface might be occurring due to modification of functional groups like amide, ether, aromatic groups in response to chromium and effluent from the fertilizer industry. Moreover, the heavy metal affects the expression and suppression of certain functional groups by interacting on the bacterial surface which might help the bacterial strain to tolerate toxicity of the heavy metal (Naik et al. 2012).

\section{Conclusions}

In the present study, we have characterized Potent indigenous bacterial strain Serratia sp. GP01 having multi-metal resistance capacity. The strain has shown the efficacy of removing toxic chromium from the culture amended with fertilizer industry effluent and $\mathrm{K}_{2} \mathrm{Cr}_{2} \mathrm{O}_{7}$ over $48 \mathrm{~h}$ of incubation. The biosorption of chromium and other heavy metals by Serratia sp. GP01 as analyzed by SEM-EDX has revealed the bioremediation potency of the isolated strain. The resistance to chromium and metal toxicity is attributed to the presence of chromate reductase gene $(C h R)$ in Serratia sp. GP01. Further antioxidant enzymes such as catalase, SOD and peroxidase were found to be higher as compared to the control condition. FTIR study revealed the changes in the status of functional groups in response to metals and the role of $\mathrm{N}-\mathrm{H}$ and $\mathrm{C}=\mathrm{O}$ functional groups on the cell surface of Serratia sp GP01. Hence, the indigenous strain Serratia sp. GP01 could be used for substantial detoxification of $\mathrm{Cr}(\mathrm{VI})$ and other heavy metals in fertilizer plant effluent. Further, work on the molecular and biochemical understanding on metal-microbe interaction could augment the treatment of toxic effluent from fertilizer industries by microbial technology using Serratia sp GP01.

nology using Serratia sp GP01.

\section{Declarations}

Acknowledgements 
We would like to acknowledge SERB, Govt. of India for financial support for developing instrumentation facilities. Financial assistance to the Centre of Excellence in Environment and Public Health by Higher Education Department of Government of Odisha under OHEPEE is also gratefully acknowledged (HE-PTCWB-02017). We are very much thankful to the technical staffs of AIRF, JNU for SEM-EDX analysis and CIF, Institute of Life Sciences at Bhubaneswar, India for sequencing of genomic DNA.

Conflict of interest The authors have no relevant financial or non-financial interests to disclose.

Funding No funding was received for conducting this study.

Author's contribution Umesh Chandra Naik designed, and reviewed the manuscript. Hrudananda Sahoo and Sushama Kumari executed the experiments, analyzed the data and wrote the manuscript. Darpa Saurav Jyethi reviewed and edited the manuscript. All the authors were involved in the critical review on writing the manuscript.

\section{References}

Aebi $H(1984)$ Catalase in vitro Methods. Enzymol 105:121-126

Aguilar-Barajas E, Paluscio E, Cervantes C, Rensing C (2008) Expression of chromate resistance genes from Shewanella sp. strain ANA-3 in Escherichia coli. FEMS microbiology letters 285:97-100

Ashok AH, Mizuno Y, Volkow ND, Howes OD (2017) Association of stimulant use with dopaminergic alterations in users of cocaine, amphetamine, or methamphetamine: a systematic review and metaanalysis. JAMA psychiatry 74:511-519

Avudainayagam S, Megharaj M, Owens G, Kookana RS, Chittleborough D, Naidu R, (2003) Chemistry of chromium in soils with emphasis on tannery waste sites. Rev Environ Contam Toxicol 178:53-91

Bagchi D, Stohs SJ, Bernard WO, Bagchi M, Preus, HG (2002) Cytotoxicity and oxidative mechanism of different forms of chromium. Toxicol 180:5-22

Baruthio F (1992) Toxic effects of chromium and its compounds. Biol Trace Elem Res 32:145-153

Bharagava RN, Mishra S (2018) Hexavalent chromium reduction potential of Cellulosimicrobium sp. isolated from common effluent treatment plant of tannery industries. Ecotoxicol Environ Saf 147:102-109

Bradford, MM (1976) A rapid and sensitive method for the quantitation of microgram quantities of protein utilizing the principle of protein-dye binding. Anal Biochem 72:248-254

Camargo FAO, Okeke BC, Bento FM (2003) In vitro reduction of hexavalent chromium by a cell-free extract of Bacillus sp. ES29 stimulated by Cu (II). Appl Microbiol Biotechnol 62:569-573 
Chance B, Maehly AC (1955) Assay of catalases and peroxidases: Methods Enzymol. Academic Press Volume 2 pp773-775

Choudhary M, Jetley UK, Khan MA, Zutshi S, Fatma T (2007) Effect of heavy metal stress on ProlineMalondialdehyde and Superoxide Dismutase activity in the Cyanobacterium Spirulina platensisS5. Ecotox Environ Saf 66: 204-209

Cosgrove DJ (1997) Relaxation in a high-stress environment: the molecular bases of extensible cell walls and cell enlargement. Plant Cell 9:1031-1041

Das S, Mishra J, Das SK, Pandey S, Rao DS, Chakraborty A, Sudarshan M, Das N, Thatoi H (2014) Investigation on mechanism of $\mathrm{Cr}(\mathrm{VI})$ reduction and removal by Bacillus amyloliquefaciens, a novel chromate tolerant bacterium isolated from chromite mine soil. Chemosphere 96:112-121

Dhanwal P, Kumar A, Dudeja S, Badgujar H, Chauhan R, Kumar A, Dhull P, Chhokar V, Beniwal V (2018) Biosorption of Heavy Metals from Aqueous Solution by Bacteria Isolated from Contaminated Soil. Water Environ Res 90:424-430

Dharmendra S, Kumar MR, Chinmayee A, Ranjan SD, Ranjan PC (2020) Assessment of marine sediment contamination and detection of their potential sources at Paradip port, East Coast of India. Res J Chem Environ 24:6

Elangovan R, Abhipsa S, Rohit B, Ligy P, Chandraraj K (2006) Reduction of $\mathrm{Cr}(\mathrm{VI})$ by a Bacillus sp.. Biotechnol Lett 28:247-252

Ewing JF, Janero DR (1995) Microplate superoxide dismutase assay employing a nonenzymatic superoxide generator. Anal Biochem 232:243-248

Faisal M, Hasnain S (2004) Comparative study of $\mathrm{Cr}(\mathrm{VI})$ uptake and reduction in industrial effluent by Ochrobactrumintermedium and Brevibacterium sp.. Biotechnol Lett 26:1623-1628

Gadd GM (2010) Metals, minerals and microbes: geomicrobiology and bioremediation. Microbiology 156:609-643

Gimeno-Garcia E, Andreu V, Boluda R (1996) Heavy metals incidence in the application of inorganic fertilizers and pesticides to rice farming soils. Environ Pollut 92:19-25

Gutierrez AM, Cabriales JJ, Vega MM (2010) Isolation and characterization of hexavalent chromiumreducing rhizospheric bacteria from a wetland. Int J Phytoremediation 12:317-334

Ilias M, Rafiqullah IM, Debnath BC, Mannan KS, Hoq MM (2011) Isolation and characterization of chromium (VI)-reducing bacteria from tannery effluents. Indian J Microbiol 51:76-81 
Jin Y, Wu S, Zeng Z, Fu Z (2017) Effects of environmental pollutants on gut microbiota. Environ Pollut 222:1-9

Joutey NT, Sayel H, Bahafid W, El Ghachtouli N (2015) Mechanisms of hexavalent chromium resistance and removal by microorganisms. Rev Environ Contam T 233:45-69

Juhnke S, Peitzsch N, Hubener N, Grobe C, Nies DH (2002) New genes involved in chromate resistance in Ralstonia metallidurans strain $\mathrm{CH} 34$. Arch Microbiol 179:15-25

Kalsoom A, Batool R, Jamil N (2021) Highly Cr (vi)-tolerant Staphylococcus simulans assisting chromate evacuation from tannery effluent. Green Process Synth 10:295-308

Khater AE (2012) Uranium and trace elements in phosphate fertilizers--Saudi Arabia. Health Phys 102:6370

Kim OS, Cho YJ, Lee K et al (2012) Introducing EzTaxon-e: a prokaryotic16S rRNA gene sequence database with phylotypes that representuncultured species. Int J Syst Evol Microbiol 62:716-721

Kowalczuk D, Pitucha M (2019) Application of FTIR method for the assessment of immobilization of active substances in the matrix of biomedical materials. Materials 12:2972

Kumar S, Stecher G, Tamura K (2016) MEGA7 molecular evolutionary genetics analysis version 7.0 for bigger dataset. Mol Biol Evol 33:1870-1874

Kwak YH, Lee DS, Kim HB (2003) Vibrio harveyi nitroreductase is also a chromate reductase. Appl Environ Microbiol 69:4390-4395

Lenartova V, Holovska K, Javorsky P (1998) The influence of mercury on the antioxidant enzyme activity of rumen bacteria Streptococcus bovis and Selenomonas ruminantium. FEMS Microbiol Ecol 27:319-325

McLean JS, Beveridge TJ, Phipps D (2000) Isolation and characterization of a chromium-reducing bacterium from a chromated copper arsenate-contaminated site. Environ Microbiol 2:611-619

Mekki A, Sayadi S (2017) Study of Heavy Metal Accumulation and Residual Toxicity in Soil Saturated with Phosphate Processing Wastewater. Water Air Soil Pollut 228: 215

Morais PV, Branco R, Francisco R (2011) Chromium resistance strategies and toxicity: what makes Ochrobactrum tritici 5 bvl1 a strain highly resistant. Biometals 24:401-410

Morgan R (2013) Soil, heavy metals, and human health. In E. C. Brevik \& L. C. Burgess (Eds.), Soils and human health. Boca Raton: CRC Press pp. 59-82

Naik UC, Srivastava S, Thakur IS (2012) Isolation and characterization of Bacillus cereus IST105 from electroplating effluent for detoxification of hexavalent chromium. Environ Sci Pollut Res 19:3005-3014 
Patra RC, Malik S, Beer M, Megharaj M, Naidu R (2010) Molecular characterization of chromium (VI) reducing potential in Gram positive bacteria isolated from contaminated sites. Soil Biol Biochem 42:18571863

Pattanapipitpaisal P, Brown NL, Macaskie LE (2001) Short Contribution: Chromate Reduction and 16SrRNA Identification of bacteria Isolated from a $\mathrm{Cr}(\mathrm{VI})$-Contaminated Site. Appl Microbiol Biotechnol 57:257-261

Rajkumar M, Nagendran R, Lee KJ, Lee WH (2005) Characterization of a Novel $\mathrm{Cr}^{6+}$ Reducing Pseudomonas sp. with Plant Growth-Promoting Potential. Curr Microbiol 50:266-271

Ramirez-Diaz MI, Diaz-Perez C, Vargas E, Riveros-Rosas H, Campos-Garcia J, Cervantes C (2008) Mechanisms of bacterial resistance to chromium compounds. Biometals 21:321-32

Sahoo H, Senapati D, Thakur IS, Naik UC (2020) Integrated bacteria-algal bioreactor for removal of toxic metals in acid mine drainage from iron ore mines. Bioresour Technolo Rep 11:100422

Samuel J, Pulimi M, Paul ML, Maurya A, Chandrasekaran N, Mukherjee A (2013) Batch and continuous flow studies of adsorptive removal of $\mathrm{Cr}(\mathrm{VI})$ by adapted bacterial consortia immobilized in alginate beads. Bioresour Technol 128:423-430

Schembri MA, Hjerrild L, Gjermansen M, Klemm P (2003) Differential expression of the Escherichia coli autoaggregation factor antigen 43. J Bacteriol 185:2236-2242

Stackebrandt E, Goebel BM (1994) Taxonomic note: a place for DNA-DNA reassociation and 16S rRNA sequence analysis in the present species definition in bacteriology. Int J Syst Evol Microbiol 44:846-849

Sultan S, Hasnain S (2005) Chromate reduction capability of a gram positive bacterium isolated from effluent of dying industry. Bull Environ ContamToxicol 75:699-706

Tamura K, Dudley J, Nei M, Kumar S (2007) MEGA4: molecular evolutionary genetics analysis (MEGA) software version 4.0. Mol Biol Evol 24:1596-1599

Tamura K, Stecher G, Peterson D, Filipski A, Kumar S (2013) MEGA6: molecular evolutionary genetics analysis version 6.0. Mol Biol Evol 30:2725-2729

Thacker U, Parikh R, Shouche Y, Madamwar D (2007) Reduction of chromate by cell-free extract of Brucella sp. isolated from Cr (VI) contaminated sites. Bioresour Technol 98:1541-1547

Thompson MR, VerBerkmoes NC, Chourey K, Shah M, Thompson DK, Hettich RL (2007) Dosagedependent proteome response of Shewanella oneidensis MR-1 to acute chromate challenge. J Proteome Res 6:1745-1757 
Zahoor A, Rehman A (2009) Isolation of $\mathrm{Cr}(\mathrm{VI})$ reducing bacteria from industrial effluents and their potential use in bioremediation of chromium containing wastewater. J Environ Sci 21:814-820

Zhang L, Liu C, Li D, Zhao Y, Zhang X, Zeng X, Yang Z, Li S (2013) Antioxidant activity of an exopolysaccharide isolated from Lactobacillus plantarum C88. Int J Biol Macromol 54:270-275

Zhou S, Dong L, Deng P, Jia Y, Bai Q, Gao J, Xiao H (2017) Reducing capacity and enzyme activity of chromate reductase in a ChrT-engineered strain. Exp Ther Med 14:2361-2366

\section{Figures}

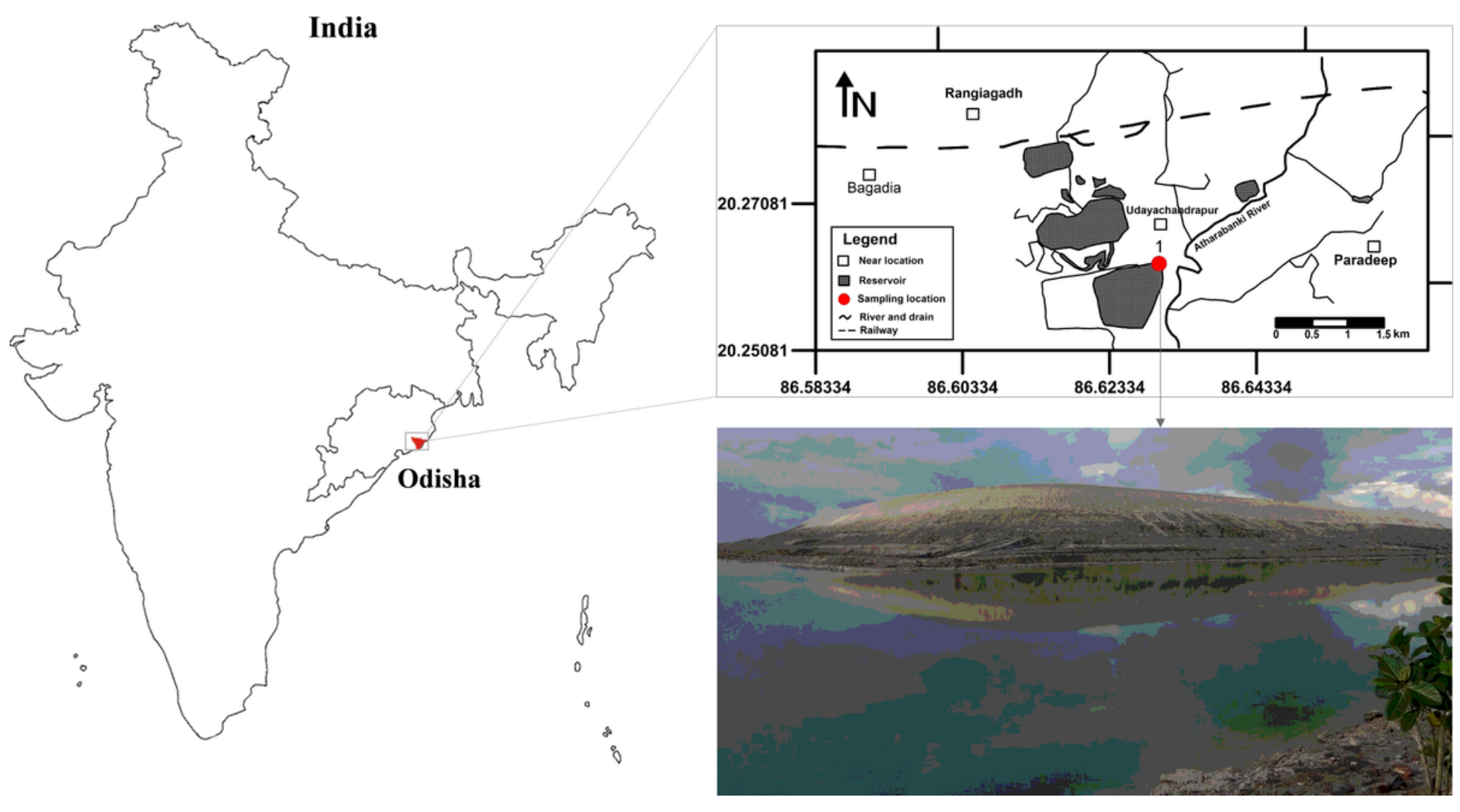

Figure 1

Location map and sampling site of industrial effluent at Paradeep region in India. 


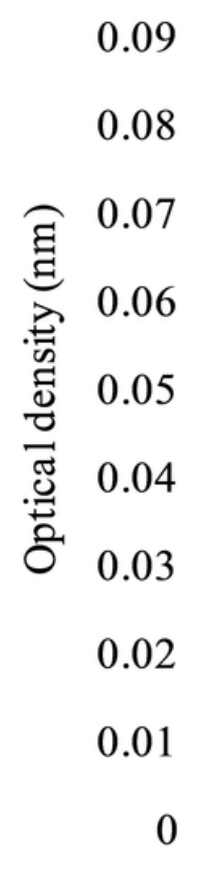

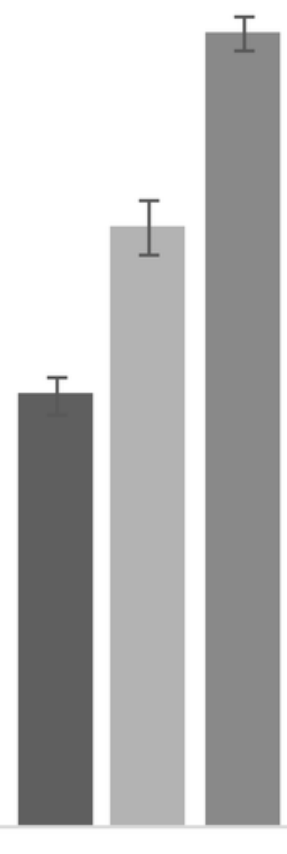

$$
0.05 \mathrm{mg} \mathrm{mL}^{-1}
$$

$0.1 \mathrm{mg} \mathrm{mL}^{-1}$

\section{Concentration of $\mathrm{K}_{2} \mathrm{Cr}_{2} \mathrm{O}_{7}$}

\section{Figure 2}

Growth pattern of potent isolated bacteria strain G1under different K2Cr2O7 concentrations.

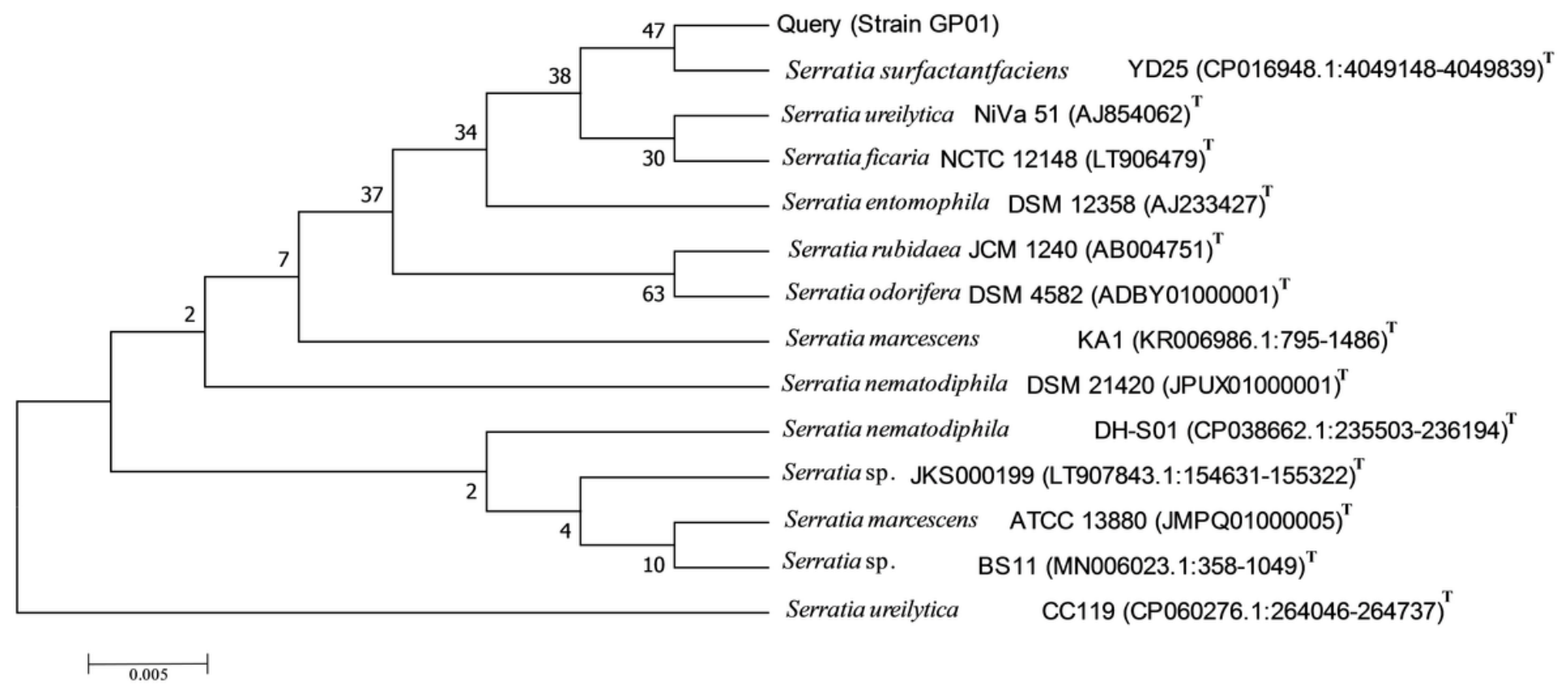

\section{Figure 3}

Growth pattern of potent isolated bacteria strain G1under different K2Cr2O7 concentrations. 


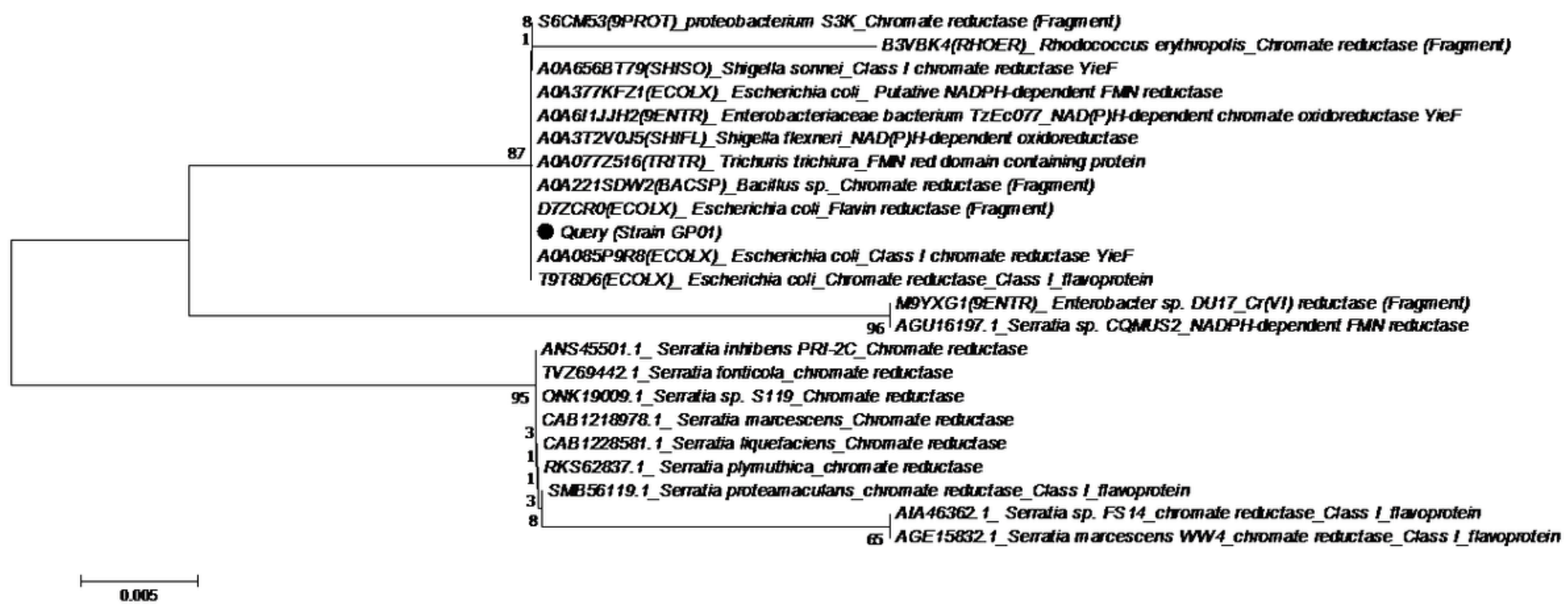

Figure 4

Phylogenetic tree constructed using neighbour-joining and 1000 bootstrap probabilities showing the relationship between chromate reductase genes ChR of Serratia sp. GP01 and ChR of other bacteria groups.

80

70

60

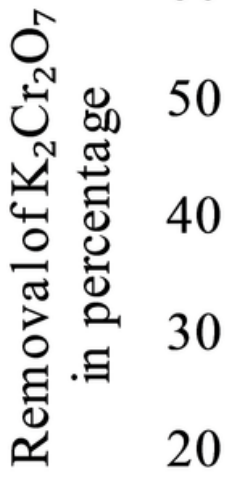

10

0
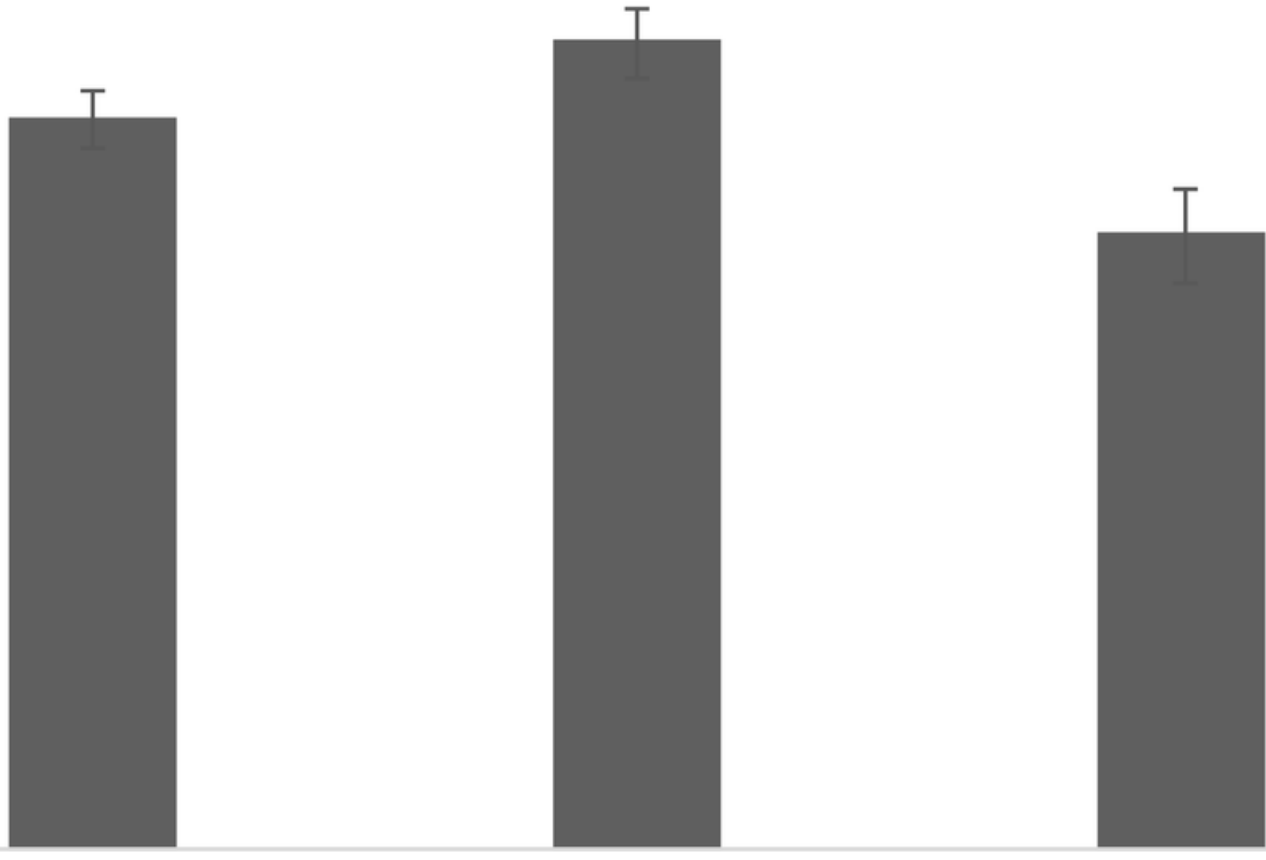

$24 \mathrm{hr}$

48hr

$72 \mathrm{hr}$

Incubation Period

\section{Figure 5}

Removal of chromium (\%) by Serratia sp. GP01 over different incubation periods. 


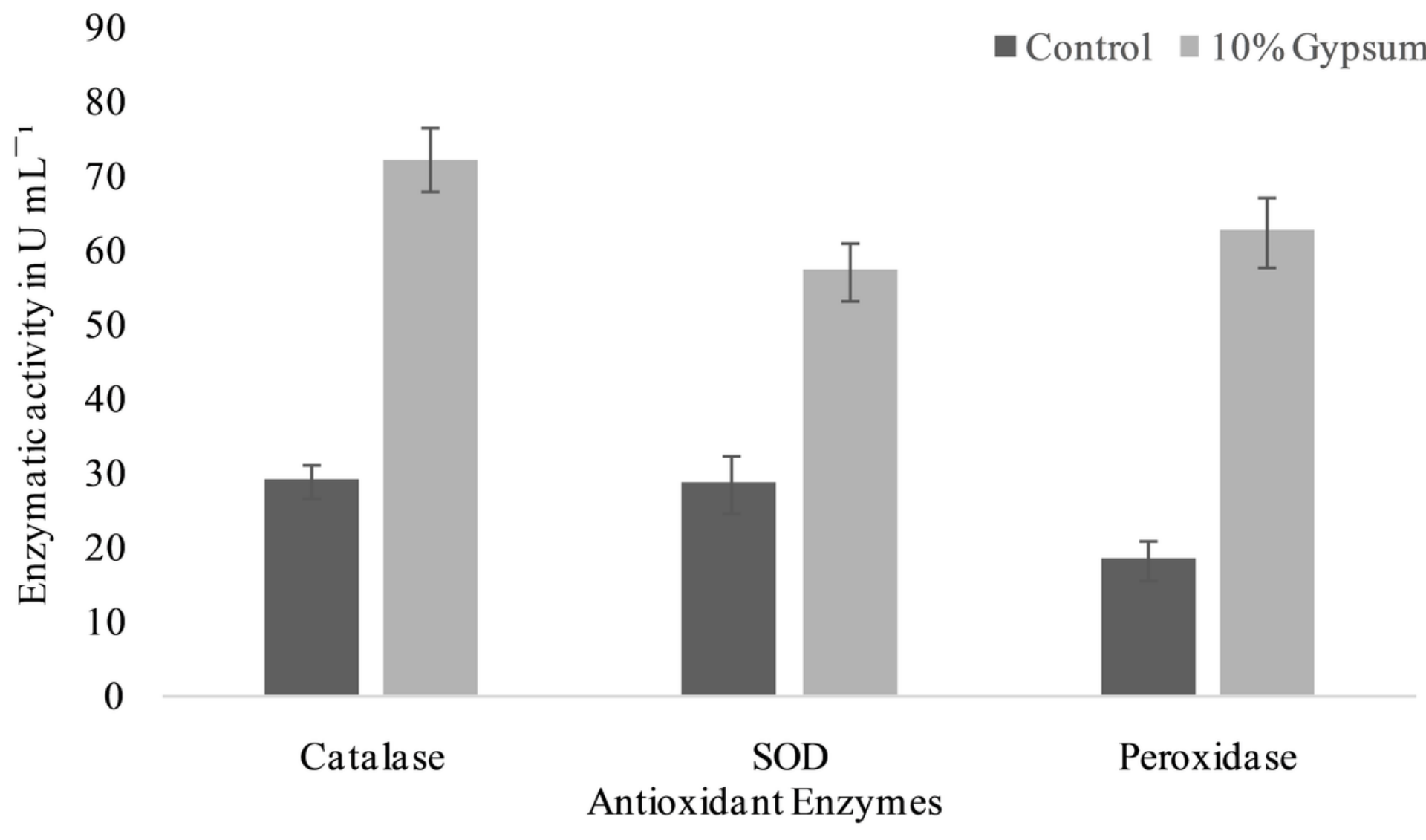

Figure 6

Production of antioxidants such as catalase, SOD and peroxidase by isolated strain Serratia sp. GP01.

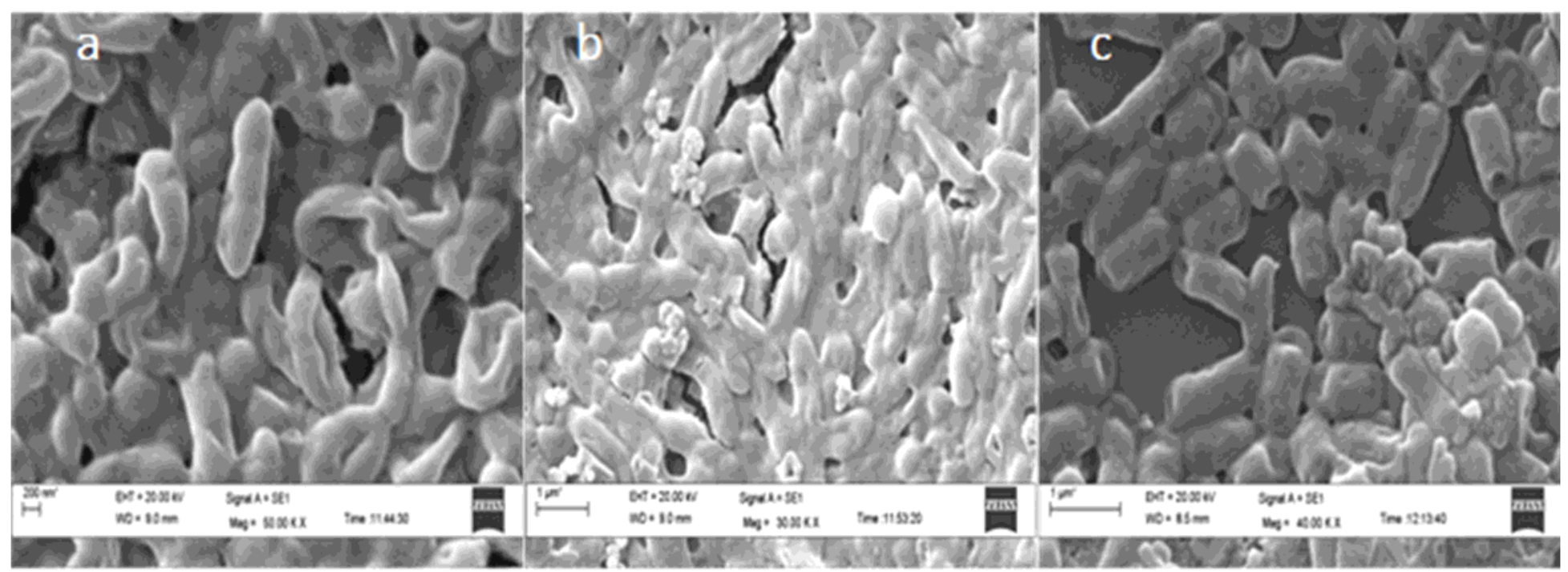

Figure 7

SEM micrographs of (a) untreated bacteria, (b) treated bacteria and (c) 10\% (v/v) effluent treated bacteria. 


\section{Supplementary Files}

This is a list of supplementary files associated with this preprint. Click to download.

- ms.archm.Supplementaryfigure.docx 